\title{
Economic Literacy Levels of Social Studies Teacher Candidates
}

\author{
Nadire Emel Akhan ${ }^{1, *}$ \\ ${ }^{1}$ Faculty of Education, Primary Education Department of Social Studies Education, Akdeniz University, Antalya, \\ Turkey \\ *Correspondence: Faculty of Education, Primary Education Department of Social Studies Education, Antalya, \\ Turkey. E-mail: neakhan@akdeniz.edu.tr
}

Received: November 12, 2014

Accepted: December 19, 2014 Online Published: January 5, 2014

doi:10.5430/wje.v5n1p25

URL: http://dx.doi.org/10.5430/wje.v5n1p25

\begin{abstract}
The purpose of this study is to determine the levels of economic literacy - an important component of being a good citizen - among seniors studying at social studies teacher program which aims at cultivating good citizens and to find out its relationships in terms of various variables. The quantitative sample of the study was comprised of 726 senior teacher candidates studying at Social Studies Teacher Education Program of the universities from seven different regions in 2013-2014 academic year. The qualitative sample included 436 teacher candidates from the quantitative sample. An Economic Literacy Questionnaire was used to determine the economic literacy levels of teacher candidates and the questionnaire was made up of 3 sections as personal data form, economic literacy test and a student opinion form on the topics of economic literacy. The results from the study revealed that economic literacy levels of social studies teacher candidates were found to be moderate, which also seemed to be supported by the responses of teacher candidates. Based on the results, it is thought to be helpful to increase the number of economics classes in the undergraduate program in order to the increase the economic literacy levels of teacher candidates.
\end{abstract}

Keywords: social studies; social studies teacher candidate; economic literacy

\section{Introduction}

Basically a human being is a biological entity alongside being a social one. The ultimate goal of a human being is to survive and continue his existence. In order to survive, some basic needs such as food, water, clothing, housing and protection should be met. Humans make an effort to meet these needs through their everyday decisions and actions. It is these efforts of mankind that underlie the origins of the economy (Agnello \& Lucel, 2008: 254). Accordingly, the goal of economics is to search for reasons for the imbalance and inequality between the unlimited needs that change, vary and grow all the time and the scarce of resources for meeting these needs and to produce solutions and come up with measures and remedies that may help to reduce or even eliminate this imbalance (Yiğitbaş1, 1996: 3).

It is hard to visualize a society without economy or vice versa, so it can be asserted that economics began and continued with mankind. There is no doubt that mankind, since the beginning of time, has performed various activities that are characteristically "economic" such as producing, trading and protecting the goods in hand for the purpose of fulfilling their various needs. That's why people have had to cope with shortage all the time since they began to live socially and the economics therefore has always become the center of attention from the most primitive societies to the most modern ones (Altınok, 2000: 3; Savaş, 1998: 17).

Studies on economy have increased in number as people have started to understand the necessity of economics education for an effective citizenship and as the interest in this education have grown with the increased knowledge of economics. In this way, to be a powerful and productive nation in every area, the significance of economics education has been supported by both academic studies and popular media. This support today has increased the importance of economic literacy among the multiple literacies. However, as emphasized by both Gerek and Kurt (2011), it can be said that there is much unknown about economic literacy which emerges as an issue as important as alphabet literacy especially along with the recent global crisis.

Economic literacy is supposed to equip students with economic knowledge, skills and attitudes adequate enough to make better decisions in the future and to better understand their country and the world as responsible, hardworking and honest citizens and in their roles as producers, consumers, employees and investors (Akhan, 2010). Economic 
literacy is an important area that individuals should learn and know about as a citizenship and as the participants of worldwide economies that have been increasingly dependent on each other (Darvin, 2006: 7). Economic literacy is our ability to write and read about economic conditions that affect our material well-being. Economic literacy is our ability to understand, discuss and respond to the events that shape our economic environment. It is essential not only to the economists but to everyone from child to adult (Jacob, 1995: xi, xii). In short, economic literacy can be defined as the ability to use a group of consistent concepts agreed on to find answers to practical questions of everyday life (Anthony, Smith and Miller, 2014:1).

Economic literacy education provided by schools is important since it prepares the young to take economy-based decisions in their private life and also in their social life as a citizen. Students need to comprehend and use correctly the basic economic concepts to make rational decisions in this complex and constantly changing world. Thanks to the knowledge of economics and ability to take right decisions, students as being skillful in economic literacy will be ready to play a role more productively in the society in the 21st century (LSSCS, 1997: 60).

Private economic educators listed below the topics necessary for students to know and to do to attain economic literacy (FSFS, 2007: 53): "Financial responsibility and decision making, income and careers, planning and money management, credit and debt, risk management and insurance, saving and investing." These topics of economic literacy become a means that allows people to understand economy and they demonstrate them how to interpret situations that might affect them directly or indirectly. They help individuals gain competence in making social decisions and understanding economic subjects that could be used personally and throughout life. Students need to know these basic economic principles before they give their opinions about economic matters that might affect their life.

Studying on the views of youth on economic issues, Ingles and O'Brien (1985) found that students receiving economics education were stronger supporter of their country's economic system and had a higher confidence in business life and also that these students felt a greater personal productivity in terms of dealing with economy (Cited in: Johnson,1990: 18). It is not the purpose of economic literacy to make students an expert in economy but to make them understand economic matters at local and global level and take decisions for their own future (Schug, 1985: 195). Today's economic conditions require that economics education be included in school curriculum to make students successful in their life. Young people can understand global economy only when they have learned economic subjects and the steps taken on this way ensure success for the economic system of their country. It will bring future citizens an advantage in all areas to enhance thinking skills of young people in economic issues besides increasing their economic literacy in other areas (Schug \& Lopus, 2008: 360); because every human being is supposed to be a producer and a consumer and also to follow the economic policy of the country no matter what socioeconomic or socio cultural environment $\mathrm{s} / \mathrm{he}$ is in. Economic literacy, for that reason, is crucial to the young people of the 21 st century.

There are important factors at schools that affect economic literacy; one of them is that teachers have a good knowledge in the field and they can provide basic knowledge of economics for the students. Yet, the academic staff who train teachers playing a key role in teaching economic subjects to primary school students are not experienced enough in the development and application of economics curriculum and in the teaching methods, as well. For that reason, the knowledge of economics of primary school teachers could remain ineffective in running a satisfying economics education program (Vargha, 2004: 28).

Studies show that the economic knowledge of teachers has a direct effect on the performance of students. In this sense, teachers firstly convince their students that the economics education is necessary at the primary education level. Besides providing knowledge of economics, teachers need to show students how to put this knowledge into practice and contribute to the development of their ability to take economic-based decisions (Meszaros \& Suiter, 1998; Riabova, 2003: 34). The results of the Morgan's study (1991) on the relationship between teacher training and students' understanding of economics at primary education level.also indicate the importance of teacher training in economic subjects.

Studies investigating the competencies of students educated by teachers who have participated in economic programs indicated that these students have a better cognitive ability to make sense of economic concepts compared to those who study economics with teachers lacking experiences of such programs. For instance, Becker (1975) reported that levels of students taught by teachers who have received economics education were higher than the levels of those who were educated by teachers with no economics education background. Similarly, Highsmith, Thornton and Vredeveld (1977) found in their study a strong positive connection between student performance and teacher training in economics. Walstad (1978) reported greater impact of seminars on teachers' understanding of economics. 
Moreover, materials for economy-based problem solving skills provided by a well-trained teacher help primary school students to be better in understanding economy and developing an attitude towards economy and in problem-solving skill and developing an attitude towards this skill (Cited in: Racich, 1982).

Thornton (2005) indicates social studies teachers as the guards of the curriculum. While teaching the objectives within the curriculum, they are influenced by their value judgments, beliefs, capabilities or talents concerning teaching. Whether a teacher's keeping the door open, half open or completely closed affects student's learning directly while they are teaching the curriculum subjects. Our expectancy is that social studies teacher candidates open their doors willingly and gladly in their classes to teach economics when they become the guards of the curriculum (Cited in Anthony, Smith and Miller, 2014:1). If teacher candidates have low economic literacy and have no self-confidence in teaching economics subjects during pre-service period, this will prevent them from making their students acquire economics skills in social studies classes (McGowan, 2009; cited in: Anthony, Smith and Miller, 2014). Accordingly, the purpose of this study is to determine the levels of economic literacy - an important component of being a good citizen - among seniors studying at social studies teacher education program which aims to cultivate good citizens and to find out its relationships in terms of various variables.

\section{Method}

This study adopted a mixed-method where quantitative and qualitative approaches were used together. Such mixed-methods using quantitative-qualitative approaches together help the researcher minimize the biases that could result from the researcher himself/herself and from the nature of the study during the research process and they increase the quality of the study conducted. Suhonen (2009), Vitale, Armenakis and Feild (2008) argued that a large variety of data sources in a study using a mixed-method help the study findings be more valid. For Sidekli (2013), the results from a certain method could be used to support and explain another method. This process naturally makes it possible for the researcher to give further details about the research data. Johnson and Onwuegbuzie (2004) stated that mixed-method can answer the research questions in a larger and wider perspective.

The rationale behind using a mixed-method in this study is the principle of complementarity which is one of the five purposes defined by Greene et al. (1989) and Giannakaki (2005). Complementarity uses the results from the other method in elaboration, illustration, enhancement and clarification of the results from one method. Quantitative and qualitative data in the complementary mixed-method is used to make the study richer and more detailed by measuring overlapping but different phenomena; in this way, each data analysis complements the other (Cited in Baki and Gökçek, 2012:4).

\subsection{Sample / Study Group}

The quantitative sample of the study comprised 726 senior teacher candidates studying at Social Studies Teacher Education Program of the universities from seven different regions in 2013-2014 academic year. Using a maximum variation sampling method, this study included in the sample the universities from regions with different socio cultural backgrounds since it aims to extend the generalizability to Turkey, to describe the problem in a wider framework and to get important and strong clues about the values of the universe (Büyüköztürk, Çakmak, Akgün, Karadeniz and Demirel, 2010).

The qualitative sample was composed of 436 teacher candidates from the universities included in the quantitative sample who answered the qualitative questions completely and correctly. Demographics of the study group were presented in the table below:

Table 1. Distribution of the Sample/Study Group by University Regions

\begin{tabular}{lccc}
\hline $\begin{array}{l}\text { University } \\
\text { Regions }\end{array}$ & $\begin{array}{c}\text { Quantitative } \\
\text { f }\end{array}$ & $\begin{array}{c}\text { Quantitative } \\
\text { \% }\end{array}$ & $\begin{array}{c}\text { Qualitative } \\
\text { f }\end{array}$ \\
\hline Mediterranean Region & 103 & 14,2 & 74 \\
Eastern Anatolia & 102 & 14,1 & 48 \\
Aegean Region & 105 & 14,5 & 53 \\
Southeastern Anatolia & 102 & 14,1 & 57 \\
Central Anatolia & 110 & 15,2 & 78 \\
Black Sea & 104 & 14,3 & 65 \\
Marmara & 100 & 13,8 & 61 \\
Total & 726 & 100,0 & 436 \\
\hline
\end{tabular}


The quantitative sample column in Table 1 shows that Central Anatolia Region with a percentage of $15,15 \%(110)$ is the leading region in terms of the number of social studies teacher candidates while Marmara Region appears at the bottom of the list with a percentage of $13,77 \%(100)$. It is seen that in general the distribution of teacher candidates by the region is similar. As for the qualitative sample, the Central Anatolia Region again leads with the most teacher candidates (78) as opposed to the lowest number of candidates from the Eastern Anatolia (48).

Table 2. Distribution by Gender of Social Studies Teacher Candidates

\begin{tabular}{lcc}
\hline Gender & f & \% \\
\hline Female & 344 & 47,4 \\
Male & 382 & 52,6 \\
Total & 726 & 100,0 \\
\hline
\end{tabular}

Of the study group, 47,4\% (344) were females while 52,6\% (382) were male participants, as presented in Table 2. The number of females seems to be close to the number of males considering the percentages.

\subsection{Data Collection Tools}

An Economic Literacy Questionnaire was used to determine the economic literacy levels of teacher candidates and the questionnaire was made up of 3 sections as personal data form, economic literacy test and a student opinion form on the topics of economic literacy.

An Economic Literacy Questionnaire with 30 items was used to determine the economic literacy levels of teacher candidates. In the first place, the literature was examined to understand how economic literacy is measured while developing this test. Accordingly, the test was built by examining the examples in the literature (Soper, 1979; Soper \& Walstad, 1987; Walstad \& Rebeck, 2001), the topics of economic literacy, the gains from the learning areas of production, distribution and consumption in primary education and the contents of economics class in social studies undergraduate program. Besides, based on the definitions of economic literacy in the literature, the questions in the Economic Literacy Test were divided into the following subsets: "decision-making in economy, using appropriate mediums in making individual decisions, understanding systems and basic economy". The items and subsets in the Economic Literacy Questionnaire were rearranged according to the views of instructors from areas of Social Studies, Turkish Language, Assessment/Evaluation and Economics. A pilot study was conducted with another 103 seniors enrolled in social studies teaching program after putting the data collection tool into final form based on the views of these instructors. The $\mathrm{Kr} 20$ value was checked for reliability as the strength of the questionnaire items was different and this value was found to be .73 , which indicates a high internal consistency and structure validity. In the final section of the economy literacy questionnaire, four open-ended questions were asked to the teacher candidates to support the quantitative data while determining the literacy levels of these teacher candidates. These questions were framed according the views of experts in Social Studies and rearranged based on the feedbacks from these experts. The qualitative items of the questionnaire were checked in terms of appropriateness by asking them to the teacher candidates during the pilot study of quantitative data.

\subsection{Data Analysis}

Questions with correct answers were scored as " 1 " while those with incorrect or no answers were scored as "0"for the assessment of economy literacy knowledge test applied to the social studies teacher candidates. In this sense, the lowest and the highest scores from the questionnaire were " 0 " and " 30 ". The levels of economic literacy test were defined as follows: 0-5 very low-level, 6-11 low-level, 12-17 moderate-level, 18-23 high-level and 24-30 very high-level. Statistical analyses were made using SPSS version 21.0. Independent samples t-test was used to compare the differences between constituents of economic literacy and independent variables. According to the results of Levene's test, which is used to assess variance homogeneity, the variance for the independent variables was found to be ( $>$ >.05). The One-Way Analysis of Variance (ANOVA), therefore, was used for the independent samples. To make multiple comparisons between the groups for the differences, a post hoc test was conducted with the use of the Dunnett's C test.

Qualitative data of the study was analyzed through descriptive method. Data obtained through descriptive analysis was summed up and interpreted based on the pre-determined themes. The data was presented with frequencies after it was digitized. Descriptive analysis aims to present the results in an arranged and interpreted form (Yildirım and Şimşek, 2006). Data analysis was made separately by two different experts as well as by the researcher and then their analyses were compared. To calculate the reliability of the study, the following formula offered by Miles and Huberman (1994) was used: P (Agreement Rate) $=(\mathrm{Na}$ (Agreement / Na (Agreement) $+\mathrm{Nb}$ (Disagreement) $) \times 100$. 
As a result of this calculation, the reliability of the study was found $96 \%$. In addition, results were supported by the quotations from the responses of some students.

\section{Results}

\subsection{Results for the Economic Literacy Levels of Social Studies Teacher Candidates}

Economic literacy levels of social studies teacher candidates were divided into five categories as very low, low, moderate, high and very high and these categories were presented below in Table 3.

Table 3. Economic Literacy Levels of Social Studies Teacher Candidates

\begin{tabular}{lcccccccc}
\hline $\begin{array}{l}\text { Subsets of } \\
\text { Economic } \\
\text { Literacy }\end{array}$ & & $\begin{array}{c}\text { Very } \\
\text { Low }\end{array}$ & Low & Moderate & High & $\begin{array}{c}\text { Very } \\
\text { High }\end{array}$ & $\bar{x}$ & S \\
\hline \multirow{2}{*}{ Decision-Making } & Range & $0-2$ & $3-4$ & $5-6$ & $7-8$ & $9-10$ & & \\
& $\mathrm{f}$ & 106 & 371 & 198 & 34 & 17 & 4,07 & 1,69 \\
Using appropriate & $\%$ & 14,60 & 51,10 & 27,27 & 4,68 & 2,34 & & \\
mediums & Range & $0-1$ & $2-3$ & 4 & 5 & 6 & & \\
Understanding & $\mathrm{f}$ & 117 & 333 & 159 & 89 & 28 & 2,98 & 1,45 \\
systems & $\%$ & 16,11 & 45,86 & 21,90 & 12,25 & 3,85 & & \\
& Range & $0-1$ & 2 & $3-4$ & 5 & $6-7$ & & \\
Basic Economy & $\mathrm{f}$ & 93 & 141 & 362 & 89 & 41 & 3,16 & 1,50 \\
& $\%$ & 12,80 & 19,42 & 49,86 & 12,25 & 5,64 & & \\
Range & $0-1$ & 2 & $3-4$ & 5 & $6-7$ & & \\
Leverall Literacy & $\mathrm{f}$ & 86 & 122 & 341 & 126 & 51 & 3,38 & 1,49 \\
& $\%$ & 11,9 & 16,8 & 47,0 & 17,4 & 7,0 & & \\
& Range & $0-5$ & $6-11$ & $12-17$ & $18-23$ & $24-30$ & & \\
& $\mathrm{f}$ & 17 & 228 & 395 & 75 & 11 & 13,20 & 4,06 \\
\hline
\end{tabular}

As Table 3 details, for the "Decision-Making" subset of the economic literacy test, the score range was computed as follows: 0-2 very low, 3-4 low, 5-6 moderate, 7-8 high and 9-10 very high. Accordingly, the percentage of teacher candidates within the score range of $0-2$ was $14,60 \%(106)$; the percentage of the candidates within the score range of 3-4 was $51,10 \%$ (371); the percentage was $27,27(198) \%$ for the candidates within the range of 5-6; the percentage for the teacher candidates within the range of $7-8$ was calculated to be $4,68 \%$ (34) and it was $2,34 \%$ (17) for the teacher candidates that fell within the score range of 9-10. The total mean score that teacher candidates obtained in the subset "Decision-Making" was found $(\bar{x}=4,07)$, which seems to show a low level of decision making for the teacher candidates.

For the "Using Appropriate Mediums", the score range was as follow: 0-1 very low, 2-3 low, 4 moderate, 5 high and 6 very high. Accordingly, the percentage of teacher candidates within the score range of $0-1$ was $16,11 \%(117)$; the percentage was seen to be $45,86 \%$ (333) for the candidates within the score range of $2-3$; the percentage was $21,90 \%$ (159) for the candidates within the range of 4; the percentage for the teacher candidates within the range of 5 was calculated to be $12,25 \%(89)$ and it was 3,85\% (28) for the teacher candidates that fell within the score range of 6 . The total mean score that teacher candidates obtained in the subset "Using Appropriate Mediums" was found ( $\bar{x}$ $=2,98$ ), which indicates a low level of using appropriate mediums for the teacher candidates.

For the subset "Understanding Systems", the score range was calculated as follows: 0-1 very low, 2 low, 3-4 moderate, 5 high and 6-7 very high. The percentage of teacher candidates within the score range of $0-1$ was $12,80 \%$ (93); the percentage was found to be $19,42 \%$ (141) for the candidates within the score range of 2; the percentage was $49,86 \%$ (362) for the candidates within the range of 3-4; for the teacher candidates within the range of 5 the percentage was $12,25 \%(89)$ and it was $5,64 \%$ (41) for the teacher candidates within the score range of 6-7. The total mean score that teacher candidates achieved in "Understanding Systems" was $(\bar{x}=3,16)$ and this means that teacher candidates have a low level of understanding systems.

The following score range was computed for the subset "Basic Economy": 0-1 very low, 2 low, 3-4 moderate, 5 high and 6-7 very high. Accordingly, the percentage of teacher candidates within the score range of $0-1$ was $11,9 \%(86)$; the percentage was seen to be $16,8 \%$ (122) for the candidates within the score range of 2 ; the percentage was $47,0 \%$ 
(341) for the candidates within the range of 3-4; the percentage for the teacher candidates within the range of 5 was calculated to be $17,4 \%$ (126) and it was 7,0\% (51) for the teacher candidates that fell within the score range of 6-7. The total mean score that teacher candidates obtained in the subset "Basic Economy" was found $(\bar{x}=3,38)$, which demonstrates a low level for the basic economy among the teacher candidates.

When the score range was examined for the overall literacy levels of the teacher candidates, it was seen that; the percentage of teacher candidates within the score range of $0-5$ was very low with $2,4 \%$ (17); the percentage was found low with $32,4 \%$ (228) for the candidates within the score range of 6-11; the percentage was moderate with $54,4 \%$ (395) for the candidates within the range of 12-17; for the teacher candidates within the range of 18-23 the percentage was high with 10,3\% (75) and it was 1,6\% (11) for the teacher candidates within the score range of 24-30. The total mean score for the overall literacy levels was $(\bar{x}=13,20)$ and this shows that teacher candidates have an overall literacy at moderate level.

3.1.1 How Do Social Studies Teacher Candidates Interpret Their Economy Literacy Levels and The Reasons?

Table 4. Scores Given by the Teacher Candidates for Themselves

\begin{tabular}{cc}
\hline Candidates Who Rate & f \\
\hline 1 & 162 \\
2 & 153 \\
3 & 86 \\
4 & 35 \\
\hline
\end{tabular}

Social studies teacher candidates were asked to give a score out of five on their own literacy levels. None of the candidates in the study group scored themselves between 0 and 5. It can be suggested that candidates in the study group generally scored themselves low (1 and 2) on their economic literacy. It could be argued based on the results that the views of teacher candidates were in parallel with their low level of economic literacy which was explored through the Economic Literacy Test.

Some of the interpretations of the candidates who rated their level of economic literacy as 1 are as follows: "It is almost impossible to understand economic issues as they are full of unfamiliar things, so I have just a little knowledge to satisfy my needs (37)", "The economic literacy I have is just enough for myself; I have neither knowledge nor interest (51)".

Candidates who rated their level of economic literacy as 2 said: "My economic literacy is just enough to pass my exams because I haven't received a good economic education (109)", "I don't understand economic matters a lot because it is not my field of expertise (266)".

Some candidates rating their level of economic literacy as 3 said: "I know some things in general and I don't think I need to know them in details. I just follow them on the news or in the newspapers (136)", "I understand a little yet the concepts all are of foreign origin. Even if I understand them, I quickly forget them. However, I try to follow them in the newspapers (76)".

Some candidates who rated their level of economic literacy as 4 said: "I believe I am highly conscious of how to improve the economy of the nation and the country. It is really important to understand the economy. Our choices are always economical, so I try to do my best to follow it (130), "I follow the economy and the trends in the world. Perhaps, I cannot say that I am good at it but I am consistent and balanced concerning my own economy (195)"

3.1.2 How Do Social Studies Teacher Candidates Explain the economic Literacy Topic that They Know Best?

Table 5. The Topic of Economic Literacy that Social Studies Teacher Candidates Know Best

\begin{tabular}{lc}
\hline Topics of Economic Literacy & f \\
\hline Financial Responsibility and Decision Making & 18 \\
Income and Careers & 148 \\
Planning and Money Management & 20 \\
Credit and Debt & 26 \\
Risk Management and Insurance & - \\
Saving and Investment & 32 \\
I cannot explain any of them & 192 \\
\hline
\end{tabular}

Social studies teacher candidates were provided with the topics that were determined by the economic educators in the literature. They were asked to explain one or several of these topics that they know best. Results indicated that in 
general their responses turned out to be "I cannot explain any of them". Besides, none of the teacher candidates in the study group responded to "risk management and insurance". Findings from the responses of teacher candidates could be said to support the fact that teacher candidates have a low-moderate level of economic literacy.

Here are some responses from the teacher candidates who said "I cannot explain any of them"; "I have no idea about them and what is the point in knowing about them in an economic system that fuels only consumption? (18)", "I have no idea about these matters. They are not interesting to me and they are also very complicated matters. To be honest, it is boring to even mention them (152)".

Some of the teacher candidates who made explanations about "saving and investing" gave the following responses; "Every individual should know them in his/her everyday life. It is an important topic both for me and for my country (62)", "It is the topic that I know best thanks to my family. Also, political developments are affected by economic developments. This is also important to understand the investments of the government (43)".

Some teacher candidates commenting on "income and careers" gave their opinions as follows: "This is the most popular topic going around now. Every university student should think about his/her own future (389)", "Income and career are the areas we senior students are most interested in. I think I have a good grasp of it (166)".

Some statements given by the teachers explaining "planning and money management" were: "I know how to make the best use of the resources in hand and I know how to be economical with less (250)", "This is what the financial hardships have taught me most (180)".

Those who gave explanations about "credit and debt" said: "I learned a lot when I could not pay off my credit card debt. It is unlikely to be unaware of that in Turkey. This is what the capitalist system teaches us best (92)", "Recently, my parents have bought a house on mortgage and that was when I learned something about credit and debt (119)".

And finally, the candidates who shared their opinions on "financial responsibility and decision-making" said: "I conducted a research in economics class about this. So, this I think is the area that I know best (29)", "I'm trying to make correct decisions on economic matters. This is the most important issue for our own economy and also the most important one among the decisions taken by the government (57)"

3.1.3 How Do Social Studies Teacher Candidates Explain the Economic Literacy Topic That They Most Want to Learn?

Table 6. The Topic of Economic Literacy That Social Studies Teacher Candidates Most Want to Learn

\begin{tabular}{lc}
\hline Topics of Economic Literacy & f \\
\hline Financial Responsibility and Decision Making & 26 \\
Income and Careers & 103 \\
Planning and Money Management & 31 \\
Credit and Debt & 38 \\
Risk Management and Insurance & 15 \\
Saving and Investment & 47 \\
I want to learn all & 159 \\
I do not want to learn any & 17 \\
\hline
\end{tabular}

Social studies teacher candidates were given the topics that were determined by the economic educators and then asked to report the one that they would like to learn about most. Teacher candidates who wanted to learn them all were greater in number among the others. The topic they most wanted to learn about was income and careers. It therefore could be suggested that teacher candidates are willing to learn about economic issues. The fact that teacher candidates are willing to improve their low-moderate economic literacy levels reinforces their tendency especially towards the subjects that they think affect their lives directly. Attitudes towards economy constitute one of the important aspects of economic literacy. The results here seem to show that social studies teacher candidates have positive attitudes towards economic issues.

Some responses from the teacher candidates who said "I want to learn all" are as follows: "These are interrelated and important issues and I wish I could learn them all (75)" "If I were knowledgeable about them, I would be very successful. I would want to learn all of them (304)".

Some candidates reporting "I do not want to learn any" shared their opinions: "To be honest, I wouldn't want to learn any of them. They are really hard and take a lot of time (13)", "There is no need to learn such difficult matters. After all, we are not gonna be an economist (156)". 
Some explanations about "income and careers" are as follows: "Everyone has a dream of having a good career and a good income and I would want to learn it to make my life better (59)", "I have plans to make a career, so I would want to learn the key points for a better future life (102)".

Another topic that teacher candidates gave their opinions on is "credit and debt" and some candidates said: "I cannot use my credit card properly, so I must learn about this urgently (287)", "Credit and debt are risky issues and they should be learned appropriately and in time (123)".

Teacher candidates who talked about "saving and investing" reported their ideas as follows: "I have never managed to build up some savings. Maybe I can guarantee my future If I learn about saving and investing (313)", "In the present circumstances of the country, this is the first thing that we all need to learn, I think (420)".

Some of the ideas reported on "financial responsibility and decision-making" are as follows: "I would like to learn it as it is the topic that will work most for me and as it is where I have a major weakness (144)", "I am not capable of making decisions about financial issues. I would like to learn to make right decisions (232)".

And finally, some of the ideas shared by teacher candidates on "risk management and insurance" are as follows: "This is the area about which I have no idea at all. Furthermore, I would want to learn it as it will matter in the future (82)", "Risk-taking is essential to be successful in economy and that is why I would like to learn about it (30)".

3.1.4 How Do Social Studies Teacher Candidates Explain Their Economic Literacy Skills?

Table 7. Self-Assessment of Teacher Candidates on Their Economic Literacy Skills

\begin{tabular}{lcc}
\hline Economic Literacy Skills & Good At & Not Good At \\
& f & f \\
\hline Making decisions in economy & 155 & 281 \\
Using appropriate mediums while making personal decisions & 127 & 309 \\
Understanding economic systems & 72 & 364 \\
\hline
\end{tabular}

Another aspect of economic literacy includes economic skills. Three important skills come to the forefront when the economic literacy definitions are examined in the literature. To support the findings of the present study, we requested social studies teacher candidates to evaluate themselves based on these three skills. As a result, it seems that in general teacher candidates in the study group found themselves inadequate regarding economic literacy skills.

Some teacher candidates expressed their opinions as follows: "I find my decision-making skill poor in economic issues. I have difficulties even spending my own money. It might be resulting from my poor planning or lack of education in this area (256)", "I don't know using appropriate mediums in making right decisions. Rather, I do not know what these mediums are (320)", "I find economic system complicated. This prevents me from recognizing or understanding them. That's, I am not good at this job (68)", "I believe my ability to make a decision is good enough in all areas. While making decisions on economic issues, I try to act thinking multi-dimensionally and considering the results (129)", "I take into account pros and cons of my choices when I make personal decisions. My choices, therefore, have always been right. I think I am good at it (20)", "I think I can recognize the economic systems well. I can understand and interpret our own economic system (176)".

In general, the qualitative findings of the study could suggest that economic literacy levels of social studies teacher candidates are of low-moderate level, confirming the quantitative findings. It can be said that teacher candidates see themselves inadequate concerning economic knowledge and economic skills - two important components of economic literacy - yet their attitudes to learn about the economy are positive.

\subsection{Results for the Gender-Based Differences between the Economic Literacy Levels of Teacher Candidates}

Independent samples t-test was conducted to examine whether there was a significant difference in terms of gender between economic literacy scores of social studies teacher candidates.

As seen from the results in Table 8, the views of the teachers candidates on "Understanding Systems" showed a significant difference in terms of gender $\left(\mathrm{t}_{(726)}=2,104 ; \mathrm{p}>.05\right)$. Regarding the subset of Understanding Systems, the mean score for the views of female teacher candidates was $(\bar{x}=3,14)$ and it was computed as $(\bar{x}=3,37)$ for the male teacher candidates. The difference was found significant in favor of male teacher candidates. As to other subsets of economic literacy, mean scores for the male and female students were found as follow: $(\bar{x}=4.378)$ for females and $(\bar{x}=4.554)$ for males in Decision-Making; $(\bar{x}=3.011)$ for females and $(\bar{x}=2.907)$ for malesin Using Appropriate Mediums; $(\bar{x}=3.425)$ for females and $(\bar{x}=3.390)$ for males in Basic Economy; $(\bar{x}=2.730)$ for females and $(\bar{x}=$ 
2.775) for males in Overall Literacy. It was observed that although there was no significant difference in Using Appropriate Mediums and Basic Economy in terms of gender, mean scores of female teacher candidates were higher than those of males. To sum up, gender didn't play a role in causing a significant difference in economic literacy levels of teacher candidates except for the subset "Understanding Systems"

Table 8. t-Test Results for the Gender-Based Differences between Economic Literacy Levels of Teacher Candidates

\begin{tabular}{|c|c|c|c|c|c|c|c|}
\hline Subsets of Economic Literacy & Gender & $N$ & $X$ & $s d$ & $d f$ & $t$ & $p$ \\
\hline \multirow[t]{2}{*}{ Decision-Making } & Female & 344 & 4.378 & 1.710 & \multirow{2}{*}{726} & \multirow{2}{*}{1.381} & \multirow{2}{*}{.168} \\
\hline & Male & 382 & 4.554 & 1.703 & & & \\
\hline \multirow[t]{2}{*}{ Using Appropriate Mediums } & Female & 344 & 3.011 & 1.435 & \multirow{2}{*}{726} & \multirow{2}{*}{-.986} & \multirow{2}{*}{.324} \\
\hline & Male & 382 & 2.907 & 1.405 & & & \\
\hline \multirow[t]{2}{*}{ Understanding Systems } & Female & 344 & 3.141 & 1.418 & \multirow{2}{*}{726} & \multirow{2}{*}{2.104} & \multirow{2}{*}{.036} \\
\hline & Male & 382 & 3.374 & 1.540 & & & \\
\hline \multirow[t]{2}{*}{ Basic Economy } & Female & 344 & 3.425 & 1.449 & \multirow{2}{*}{726} & \multirow{2}{*}{-.318} & \multirow{2}{*}{.751} \\
\hline & Male & 382 & 3.390 & 1.519 & & & \\
\hline \multirow[t]{2}{*}{ Overall Literacy Levels } & Female & 344 & 2.730 & .718 & \multirow{2}{*}{726} & \multirow{2}{*}{.809} & \multirow{2}{*}{.419} \\
\hline & Male & 382 & 2.775 & .747 & & & \\
\hline
\end{tabular}

3.3 Results for the Differences between the Economic Literacy Levels of Teacher Candidates According to Their General Academic Average

The One-Way Analysis of Variance was conducted to determine whether there was a significant difference between economic literacy levels of social studies teacher candidates according to their general academic average

Table 9. Results of the One-Way Analysis of Variance for The Differences between Economic Literacy Levels of Social Studies Teacher Candidates According to Their General Academic Average

\begin{tabular}{lcrrrrrr}
\hline $\begin{array}{l}\text { Subsets of Economic } \\
\text { Literacy }\end{array}$ & $\begin{array}{c}\text { Source of } \\
\text { Variance }\end{array}$ & $\begin{array}{c}\text { Sum of } \\
\text { Squares }\end{array}$ & $\boldsymbol{d f}$ & $\begin{array}{c}\text { Mean } \\
\text { Squares }\end{array}$ & $\boldsymbol{F}$ & $\boldsymbol{p}$ & $\begin{array}{c}\text { Significant } \\
\text { Difference }\end{array}$ \\
\hline Decision-Making & Intergroup & 7.123 & 4 & 1.781 & .609 & .656 & \\
& Intragroup & 2083.763 & 722 & 2.923 & & & \\
Tsing Appropriate & Total & 2090.886 & 726 & & & & \\
Mediums & Intergroup & 40.514 & 4 & 10.128 & 5.147 & .000 & $1-4,1-5$, \\
& Intragroup & 1403.148 & 722 & 1.968 & & & $2-4,3-4$ \\
Understanding & Total & 1443.662 & 726 & & & & \\
Systems & Intergroup & 4.214 & 4 & 1.053 & .475 & .754 & \\
& Intragroup & 1581.036 & 722 & 2.217 & & & \\
Basic Economy & Total & 1585.249 & 726 & & & & \\
& Intergroup & 10.389 & 4 & 2.597 & 1.179 & .319 & \\
Overall Literacy & Intragroup & 1570.859 & 722 & 2.203 & & & \\
Levels & Total & 1581.248 & 726 & & & & \\
& Intergroup & 2.831 & 4 & .708 & 1.319 & .261 & \\
\hline
\end{tabular}

General Average; $1=1.50-1.99,2=2.00-2.49,3=2.50-2.99,4=3.00-3.49,5=3.50-4.00$

Results in Table 9 show that there is no significant difference between general academic averages of teacher candidates regarding their literacy levels $\left[\mathrm{F}_{(4-722)}=1.319, \mathrm{p}>.05\right]$. Economic literacy levels of teacher candidates increased with the increase in their general academic averages. However, this increase was not big enough to lead to a significant difference between general academic averages.

Economic literacy levels of teacher candidates participated in the study showed a significant difference in the subset Using Appropriate Mediums according to their general academic averages" $\left[\mathrm{F}_{(4-722)}=5.147, \mathrm{p}<.05\right]$. According to the results of the Dunnett's C test conducted to make multiple comparisons between the groups, significant differences were observed as follows; a significant difference in favor of those with a general academic average of 3.00-3.49 between the groups with a general academic average of 1.50-1.99 and 3.00-3.49, a significant difference in favor of those with a general academic average of 3.50-4.00 between the groups with a general academic average of 1.50-1.99 and 3.50-4.00, a significant difference in favor of those with a general academic average of 3.00-3.49 between the groups with a general academic average of 2.00-2.49 and 3.00-3.49 and a significant difference in favor 
of those with a general academic average of 3.00-3.49 between the groups with a general academic average of 2.50-2.99 and 3.00-3.49. Accordingly, it was found that an increase occurred in the subset "Using Appropriate Mediums" as the general academic averages of teacher candidates increased. On the other hand, general academic average didn't have an affect on causing a significant difference in economic literacy levels of teacher candidates except for the subset "Using Appropriate Mediums"

3.4 Results for the Differences Between the Economic Literacy Levels of Teacher Candidates According to the Region of Their University

The One-Way Analysis of Variance was performed to find out whether there was a significant difference between economic literacy levels of social studies teacher candidates according to the region of their university.

Table 10. Results of the One-Way Analysis of Variance for The Differences Between Economic Literacy Levels of Social Studies Teacher Candidates According To The Region of Their University

\begin{tabular}{lccccccc}
\hline $\begin{array}{l}\text { Subsets of Economic } \\
\text { Literacy }\end{array}$ & $\begin{array}{c}\text { Source of } \\
\text { Variance }\end{array}$ & $\begin{array}{c}\text { Sum of } \\
\text { Squares }\end{array}$ & $\boldsymbol{d f}$ & $\begin{array}{c}\text { Mean } \\
\text { Squares }\end{array}$ & $\boldsymbol{F}$ & $\boldsymbol{p}$ & $\begin{array}{c}\text { Significant } \\
\text { Difference }\end{array}$ \\
\hline Decision-Making & Intergroup & 112.893 & 6 & 18.816 & 6.763 & .000 & $1-2,1-3$, \\
& Intragroup & 1977.993 & 720 & 2.782 & & & $2-4,2-5$, \\
& Total & 2090.886 & 726 & & & & $2-6,2-7$ \\
Using Appropriate & Intergroup & 56.817 & 6 & 9.469 & 4.855 & .000 & $1-2,1-3$, \\
Mediums & Intragroup & 1386.845 & 720 & 1.951 & & & $1-4,1-5,1-6$ \\
& $\quad$ Total & 1443.662 & 726 & & & & \\
Understanding & Intergroup & 49.085 & 6 & 8.181 & 3.786 & .001 & $1-2,1-3$, \\
Systems & Intragroup & 1536.164 & 720 & 2.161 & & & $1-4,1-6,1-7$ \\
& $\quad$ Total & 1585.249 & 726 & & & & \\
Basic Economy & Intergroup & 59.022 & 6 & 9.837 & 4.595 & .000 & $1-2,1-3$, \\
& Intragroup & 1522.226 & 720 & 2.141 & & & $1-4,1-5$, \\
& Total & 1581.248 & 726 & & & & $1-6,1-7$ \\
Overall Literacy & Intergroup & 26.896 & 6 & 4.483 & 8.891 & .000 & $1-2,1-3$, \\
Levels & Intragroup & 358.470 & 720 & .504 & & & $1-4,1-5$, \\
& Total & 385.366 & 726 & & & & $1-6,1-7,2-7$ \\
\hline
\end{tabular}

1: Mediterranean, 2: Eastern Anatolia, 3: Aegean, 4: Southeastern Anatolia, 5: Central Anatolia, 6: Black Sea, 7: Marmara

As can be seen in the results of Table 10, there were significant differences between the economic literacy levels of social studies teacher candidates according to the region of their university $\left[\mathrm{F}_{(6-720)}=8.891, \mathrm{p}>.05\right]$. Literacy levels of social studies teacher candidates displayed a significant difference based on the region of their universities.

According to the results of the Dunnett's $\mathrm{C}$ test conducted to find out how the region of their university affected the economic literacy of teacher candidates, a significant difference was observed in "Decision-Making" between Mediterranean and Eastern Anatolia, Mediterranean and Aegean, Eastern Anatolia and Southeastern Anatolia, Eastern and Central Anatolia, Eastern Anatolia and Black Sea and finally between Eastern Anatolia and Marmara Region. All the differences were observed to be in favor of the former regions in the pairs. It was seen that Mediterranean and Eastern Anatolia Regions, compared to other regions, had a positive effect on "Decision-Making".

According to the results of the Dunnett's $\mathrm{C}$ test conducted to find out how the region of their university affected the economic literacy of teacher candidates, a significant difference was found in "Using Appropriate Mediums" between Mediterranean and Eastern Anatolia, Mediterranean and Aegean, Mediterranean and Southeastern Anatolia, Mediterranean and Central Anatolia, and finally between Mediterranean and Black Sea Region. All the differences between the pairs were observed to be in favor of the Mediterranean Region. It was observed that Mediterranean Region had a positive impact on "Using Appropriate Mediums" when compared to other regions.

According to the results of the Dunnett's $\mathrm{C}$ test conducted to find out how the region of their university affected the economic literacy of teacher candidates, significant differences were found in "Understanding Systems" between Mediterranean and the rest of the other regions (in the order given; Eastern Anatolia, Aegean, Southeastern Anatolia, Black Seaand Marmara Regions). Once more time, all the differences between Mediterranean and the others were observed to be in favor of the Mediterranean Region. It was seen that Mediterranean Region positively affected the subset "Understanding Systems" compared to the rest of the regions. 
The results of the Dunnett's C test revealed significant differences in "Basic Economy" between Mediterranean Region and the other regions (in the order given; Eastern Anatolia, Aegean, Southeastern Anatolia, Central Anatolia, Black Sea and Marmara Regions). Accordingly, the subset "Basic Economy" was positively affected by the Mediterranean Region compared to the other regions.

The results of the Dunnett's C test indicated that significant differences existed in "Using Appropriate Mediums" between Mediterranean Region and each of other regions (in the order given; Eastern Anatolia, Aegean, Southeastern Anatolia, Central Anatolia, Black Sea and Marmara Regions) in favor of Mediterranean Region. A significant difference was also observed between Eastern Anatolia and Marmara Region in favor of the former one. In this sense, Mediterranean Region and Eastern Anatolia Region were seen to have a positive effect on "Using Appropriate Mediums" in comparison with the other regions.

3.5 Results for the Differences between Economic Literacy Levels of Social Studies Teacher Candidates According to Their Family Income

The One-Way Analysis of Variance was performed to find out whether there was a significant difference between economic literacy levels of social studies teacher candidates according to their family income.

Table 11. Results of the One-Way Analysis of Variance for the Differences between Economic Literacy Levels of Social Studies Teacher Candidates According to Their Family Income

\begin{tabular}{lcrrrrrr}
\hline $\begin{array}{l}\text { Subsets of } \\
\text { Economic } \\
\text { Literacy }\end{array}$ & $\begin{array}{c}\text { Source of } \\
\text { Variance }\end{array}$ & $\begin{array}{c}\text { Sum of } \\
\text { Squares }\end{array}$ & $\boldsymbol{d f}$ & $\begin{array}{c}\text { Mean } \\
\text { Squares }\end{array}$ & $\boldsymbol{F}$ & $\boldsymbol{p}$ & $\begin{array}{c}\text { Significant } \\
\text { Difference }\end{array}$ \\
\hline Decision-Making & Intergroup & 8.274 & 3 & 2.758 & .961 & .41 & \\
& Intragroup & 2071.40 & 722 & 2.869 & & & \\
Using & $\quad$ Total & 2079.68 & 725 & & & & \\
Appropriate & Intergroup & 22.227 & 3 & & 3.536 & .014 & $3-1$ \\
Mediums & Intragroup & 1512.66 & 722 & & & & \\
Understanding & $\quad$ Total & 1534.88 & 725 & & & & \\
Systems & Intergroup & 32.867 & 3 & 10.956 & 4.921 & .002 & $3-1$ \\
& Intragroup & 1607.29 & 722 & 2.226 & & & \\
Basic Economy & Total & 1640.16 & 725 & & & & \\
& Intergroup & 22.647 & 3 & 7.549 & 3.396 & .018 & $3-2$ \\
& Intragroup & 1604.90 & 722 & 2.223 & & & \\
Overall Literacy & Total & 1627.54 & 725 & & & & \\
Levels & Intergroup & 237.46 & 3 & 79.153 & 4.874 & .002 & $2-1,3-1$ \\
& Intragroup & 11725.17 & 722 & 16.240 & & & \\
\hline
\end{tabular}

Financial situation1: Live comfortably, 2: Meet expenses/extras, 3: Just enough for basics, 4: Not enough for basics

As seen in Table 11, economic literacy levels of social studies teacher candidates displayed significant differences according to their family's financial situation $\left[\mathrm{F}_{(5-720)}=8.891, \mathrm{p}>.05\right]$. These results suggest that family income and economic literacy levels of social studies teachers show significance at 0.005 level.

According to the results of the Dunnett's $\mathrm{C}$ test conducted to find out how the family income affected the economic literacy levels of teacher candidates, there is a significant difference in "Using Appropriate Mediums" between the financial situations Just Enough for Basicsand Live Comfortably in favor of Just Enough for Basics. Accordingly, the subset "Using Appropriate Mediums" was positively affected by the family income of the teacher candidates which is Just Enough for Basics.

The results of the Dunnett's C test indicated that a significant difference existed in "Understanding Systems" between the financial situations Just Enough for Basics and Live Comfortably in favor of the former one. It could be suggested that the financial situation Just Enough for Basics among others positively affected the subset "Understanding Systems"

According to the results of the Dunnett's $C$ test conducted to find out the effects of family income on literacy levels of teacher candidates, a significant difference was found in "Basic Economy" between the financial situations Just Enough for Basics and Meet Expenses/Extras in favor of the former. It could be said that the financial situation Just Enough for Basics had a positive effect on the subset "Basic Economy" when compared the other financial situations. 
Finally, Results of the post hoc comparisons using the Dunnett's $C$ test revealeda significant difference in overall literacy levels between Meet Expenses/Extras and Live Comfortably and between Just Enough for Basics and Live Comfortably in favor of the former ones. Therefore, it could be suggested that the financial situation Just Enough for Basics, compared to others, positively affected the economic literacy levels.

\section{Discussion, Conclusion and Implications}

Nearly in all parts of the society, economy is one of the major areas that people talk about, criticize and follow in the written and visual media. But despite this attention, economy is perceived as a social sciences discipline that can be described as unpopular, complex or challenging. In fact, beginning from their childhood individuals encounter this phenomenon, which they both take interest in and hesitate about. Moreover, almost all their choices in the out-of-school life are related to economy. Subjects of economy that they study at school have no purpose of training them as an economist. Economy is just a step for their purpose in becoming a good citizen. Students learn the subjects of economy mostly in social studies classes because the primary goal of social studies classes is to cultivate a good individual and a good citizen. In this sense, economy as an indispensable component of becoming a good citizen is one of the main disciplines of social studies course. For that reason, it is important for social studies teachers to teach their students this discipline within the framework of social studies course. Accordingly, the present this study aims to determine the levels of economic literacy - an important component of being a good citizen among seniors studying at social studies teacher education program aiming at cultivating good citizens and to find out its relationships in terms of various variables.

In general, the results of the study showed that teacher candidates have a moderate level of economic literacy. This is also supported by the responses of the teacher candidates. It is possible to argue that teacher candidates do not find themselves adequate in their economic knowledge and skill. Results of this study can be said to be similar to those in the literature. Studies conducted on economic literacy of teachers (McKenzie, 1971; Walstad, 1979: cited in Anthony, Smith and Miller, 2014; Grimes, Milleaand Thomas, 2007; Sosin, Dick, \&Reiser, 1997; Ramsett, 1972) have shown that primary school teachers lack the economic literacy needed to teach economic subjects correctly. Studies carried out with teacher candidates also suggest evidence of low economic literacy levels among these teacher candidates (Anthony, Smith and Miller, 2014). In addition, Kıliçoğlu and Akhan (2014) reported in their study that social studies teacher candidates either misunderstand the concepts of economy or their knowledge of economy concepts is quite limited. Gerek and Kurt (2008) reported moderate level of economic literacy among higher education students. Furthermore, Gerek and Kurt (2010) found in another study that students studying at the Department of Computer and Instructional Technologies do not have economic literacy skills at higher levels since courses to develop economic literacy skills are not included in the study program. It was also emphasized that economic literacy as an indicator of economic competence is an area neglected in most higher education programs except for Faculty of Economics and Administrative Sciences

Another result of the study is that teacher candidates are willing to learn academic subjects. It therefore can be said that teacher candidates have positive attitudes towards learning academic subjects. Nevertheless, studies have revealed that teachers are unwilling and uneasy and have negative attitudes while teaching academic subjects and they are more concerned about economy as compared to any other social sciences discipline (Walstad \& Watts, 1985; Highsmith, 1990; Patterson 2002; Vargha, 2004). On the other hand, Staubs (2007) asserted that as teacher candidates are more idealist during school years, their beliefs and attitudes to do with teaching economic subjects within the Social Studies program could be positive. Akhan (2014) also reported positive attitudes among seniors in social studies program towards economics course and teaching of economics. These results provide evidence that teacher candidates, though they do not find their economic literacy levels satisfying, are willing to learn about economy.

This study also examined the economic literacy levels of social studies teacher candidates in terms of different variables. Firstly, it measured the effect of gender on economic literacy levels and found a significant difference only in the subset Understanding Systems in favour of male teacher candidates. Yet, in their study conducted with teachers, Grimes, Millea and Thomas (2007) found that economic literacy levels were lower among female teachers. Studies carried out at primary school level revealed that gender does not make a difference in attitudes to economics (Kourilsky, 1987; Akhan, 2010). In the light of these results, it appears that further research is needed to measure the effect of gender on economic literacy.

As to the effect of academic success on the economic literacy of social studies teacher candidates, it was seen that economic literacy levels of teacher candidates improved in parallel with their general academic averages though not 
at a significant level. It was found that the effect of general academic averages was not big enough to cause a significant difference except the subset of Using Appropriate Mediums. Kushner, Carey, Dedrick and Wallace (1995) found that teachers with a higher academic success are more interested in academics classes and develop more positive attitudes towards those classes (Cited in Staubs, 2007).In the studies ahead, therefore, the performance in economics classes besides general academic average should be taken into consideration.

Being in the regions of Mediterranean and Eastern Anatolia as compared to others was observed to have a positive impact on economic literacy level, which was another finding of the study referring to the effect of the region of the university on the academic literacy levels of teacher candidates. This study included in its sample the universities in the regions with different socio-economic backgrounds. While choosing the regions, the socio-economic indicators determined by Gül and Çevik (2007) were used for the seven geographical regions of Turkey. Results indicated that economic literacy is more common in the Mediterranean Region - a region with medium socioeconomic status - and in the Eastern Anatolia Region -a region with low socioeconomic status. Nevertheless, studies showing that economic literacy is closely associated with the level of income (McKenzie (1970); Williams (1970): cited in. Staubs, 2007) offer evidence that socioeconomic status might cause differences in learning. Moreover, Johnson (1990) found that lower socioeconomic status is associated with increased economic alienation. Finally, comparing the family income and economic literacy levels of teacher candidates, this study found a negative correlation between family income and economy literacy levels; the level of economic literacy goes up as the family income decreases. However, Grimes, Millea and Thomas (2007) reported that teachers' understanding of economy is positively associated with annual income of the family and life experiences of adults have a central place in understanding economic concepts.

Among the variables of this study, socioeconomic status and family income show consistency with the literature. This can be explained by the perception of economic conditions in Turkey which is different from the economic perceptions in other countries. It might be thought that having a low socioeconomic status or growing up in a family with a low income will strengthen the tendency towards economy. It would be helpful to display this difference through new studies and particularly through qualitative studies.

Literature about economic literacy points to the importance of learning economics as an indispensable part of being a good citizen, beginning from childhood. What is needed to do that is a good curriculum and good teachers to follow this curriculum. Accordingly, ways to improve economic literacy of teachers and to enrich the contents of curriculum need to be found after a thorough examination of these two elements. In the first place, further qualitative studies are needed to discuss economic literacy of teachers in service and of teacher candidates in terms of cause and effect relationship. Then, steps can be taken to improve their economic literacy. In addition, undergraduate programs should be enriched with courses comprising economic subjects to develop economic literacy competence of teacher candidates. Desires of teacher candidates to learn economic issues should be regarded as an opportunity and their interest in economy should be fostered through elective courses. To this end, instructors to teach economics need to be trained well. It would be helpful to direct instructors towards conducting studies in economics at the doctoral level. Economics should be included in the core courses at universities considering that not only social studies teacher candidates but also all university students as good citizens will be a link in the chain of production-distribution-consumption. Economic literacy education gains importance beginning from childhood as children go through a number of economic-based experiences in the family. For that reason, it should be kept in mind that economy education will also contribute to the parents of the future as a part of university education.

\section{References}

Agnello, M. F., \& Lucel, T. A. (2008). Toward a critical economic literacy: Preparing K-12 learners to be economically literate adults. In: D. E. Lund, \& P.R. Carr, (eds.) Doing democracy: Striving for political literacy and social justice (pp. 247-265). NewYork: Peter Lang Publishing.

Akhan, N. E. (2010). İlköğretim sosyal bilgiler öğrencilerinde ekonomi okuryazarllğının durumu ve gelişstirilmesi (The case and development of economic literacy of the students in social sciences in primary school). (Unpublished Doctoral Thesis) Gazi Universitiy / Institute of Education Sciences, Ankara.

Akhan, N. E. (2014). Examining the attitudes of pre-service social studies teachers towards economics courses. International Journal of Academic Research, 6(1), 340-348. http://dx.doi.org/10.7813/2075-4124.2014/6-1/B.46

Altınok, S. (2000). İktisada giriş (Introduction to economics). Konya: Kuzucular Publishing.

Anthony, K.V., Smith, R.C., \& Miller, N.C. (2014). Preservice elementary teachers' economic literacy: Closing Gates to full implementation of the social studies curriculum. The Journal of Social Studies Research, 39(1), 
29-37. http://dx.doi.org/10.1016/j.jssr.2014.04.001

Baki, A., \& Gökçek, T. (2012). Karma yöntem araştırmalarına genel bir bakış (A general overview of mixed method researches). Electronic Social Sciences Journal, 11(42), 1-21.

Büyüköztürk, Ş., Çakmak, E. K., Akgün, Ö. E., Karadeniz, Ş., \& Demirel, F. (2010). Bilimsel araştırma yöntemleri (Scientific research methods). (5nd ed.). Ankara: Pegem Akademi Publishing.

Darvin, M. W. (2006). Economics framework for the 2006 national assessment of educational progress. Washington: National Assessment Governing Board U.S. Department of Education.

FSFS (Financial Smarts For Students) (2007). National standards in K-12 personal finance education. Washington: JumpStart Coalition for Personal Financial Literacy. Retrieved August 12, 2008, from http://www.pueblo.gsa.gov/cic_text/education/jumpstart/k-12.pdf

Gerek, S., \& Kurt, A. A. (2008). Economic literacy of university students: A sample from Anadolu University. Retrieved July 16, 2009, from http://papers.ssrn.com/sol3/papers.cfm?abstract_id=1137610

Gerek, S., \& Kurt, A. A. (2010). Bilgisayar ve öğretim teknolojileri eğitimi bölümlerinde ekonomi okuryazarlığına ilişkin göstergeler (Economic literacy indicators at the department of computer education \& instructional technologies). Gaziantep University Social Sciences Journal, 9(1), 87-97.

Gerek, S., \& Kurt, A. A. (2011). Ekonomi okuryazarlığı ölçeğinin geçerlik ve güvenirlik çalışması (Economic literacy scale: Validity-reliability study). Uludağ University Faculty of Economics and Administrative Sciences Journal, $X X X(1), 59-73$.

Grimes, P., Millea, M., \& Thomas, M. (2007). Testing the economic literacy of K-12 teachers: A state-wide baseline analysis. Retrieved October 12, 2014, from http://dx.doi.org/10.2139/ssrn.962781

Gül, H. E., \& Çevik, B. (2014). 2010 ve 2012 verileriyle Türkiye'de illerin gelişmişlik düzeyi araştırması (A research into the development levels of provinces in turkey with 2010 and 2012 data). İş Bank Publications. Retrieved October 18, 2014, from http://ekonomi.isbank.com.tr/UserFiles/pdf/ar_03_2012.pdf

Highsmith, R. (1990). How do we stand in high school economics today? Social Education, 54(2), 81-83.

Jacob, D. R. (1995). Economic literacy: What everyone needs to know about money \& markets. New York: Published by Three Rivers Press.

Johnson, B., \& Onwuegbuzie, A. (2004). Mixed methodsresarch: A research paradigm whose time has come. Educational Researcher, 33(7), 14-26.

Johnson, B. C. (1990). A status study of economic education in michigan elementary schools. Degree Of Doctor Of Education Department Of Educational Leadership. Michigan: Western Michigan University.

Kılıçoğlu, G., \& Akhan, N.E. (2014). Sosyal bilgiler öğretmen adaylarının ekonomi kavramlarını anlama düzeyleri (The levels of understanding of the social studies teacher candidates towards the economy concepts). Electronic Social Sciences Journal, 13(51), 209-225.

Kourilsky, M. L. (1987). Children's learning of economics: The imperative and the hurdles. Theory Into Practice, 3, 198-205. http://dx.doi.org/10.1080/00405848709543274

LSSCS (Louisiana Social Studies Content Standards) (1997). State standards for curriculum development. Retrieved August 12, 2008, from http://www.doe.state.la.us/lde/uploads/2912.pdf.

Meszaros, B., \& Suiter, M. (1998). The case for economics in the elementary classroom. Region, 12(4), 104-109.

Miles, M.B., \& Huberman, A.M. (1994). Qualitative data analysis (2nd ed.). Thousand Oaks, CA: Sage.

Morgan, J. C. (1991). Using econ and me to teach economics to children in primary grades. The Social Studies, 82(5), 195-197. http://dx.doi.org/10.1080/00377996.1991.9958336

Patterson, J. (2002). Slavery revisited: Using economics reasoning to teach about the past and present. The Social Studies, 93(1), 40-43. http://dx.doi.org/10.1080/00377990209599879

Racich, M. J. (1982). Economic education in the elementary grades: Implementation and evaluation. A Dissertation Submitted in Partial Satisfaction of the Requirements of the Degree of Doctor of Education. Illinois State University.

Ramsett, D. E. (1972). Toward improving economic education in the elementary grades. The Journal of Economic Education, 4(1), 30-35. http://dx.doi.org/10.1080/00220485.1972.10845361 
Riabova, I. G. (2003). Training the teacher for the economic education of younger students. Russian Education and Society, 45(8), 26-35. http://dx.doi.org/10.2753/RES1060-9393450826

Savaş, V.F. (1998). Iktisadın tarihi (History of economics). İstanbul: Avcıl Press Publication.

Schug, M., \& Lopus J. (2008). Economic and financial education for the 21st century. Social Education, 72(7), $359-362$.

Schug, M. C. (1985). Introduction. In M. C. Schug (Ed.), Economics in the school curriculum, K-12. Washington, D.C.: The Joint Council on Economic Education and the National Education Association.

Sidekli, S. (2013). Media literacy: Perspectives from elementary school children'sviews. International Journal of Academic Research, 5(2), 201-210. http://dx.doi.org/10.7813/2075-4124.2013/5-2/B.31

Soper, J. C. (1979). Test of economic literacy: Discussion guide and rationale. New York: Joint Council on Economic Education.

Soper, J. C., \& Walstad, W. B. (1987). The test of economic literacy: Examiner's manual (3nd ed.). New York: Joint Council on Economic Education.

Sosin, K., Dick, J., \& Reiser, M. (1997). Determinants of achievement of economics concepts by elementary school students. Journal of Economic Education, 28(1), 100-121. http://dx.doi.org/10.1080/00220489709595912

Staubs, M. O. (2007). Economics education: Attitudes and practices of elementary and middle grade teacher candidates. Degree of Doctor of Philosophy in the Department of Elementary Education in the Graduate School of the University of Alabama. Alabama: Tuscaloosa.

Suhonen, J. (2009). Qualitative and mixed method research. Scientific Methodology in Computer Science, Fall, I-XIII.

Vargha, L. D. (2004). Buyer beware! Economics activities for middle school students. The Social Studies, 95(1), 27-32. http://dx.doi.org/10.3200/TSSS.95.1.27-32

Vitale, D. C., Armenakis, A. A., \& Feild, H. S. (2008). Integrating qualitative and quantitative methods for organization aldiagnosis. Journal of Mixed Methods Research, 2(1), 87-105. http://dx.doi.org/10.1177/1558689807309968

Walstad, W., \& Watts, M. (1985). Teaching economics in the schools: A review of the survey findings. Journal of Economic Education, 16(2), 135-146. http://dx.doi.org/10.1080/00220485.1985.10845109

Walstad, W. B., \& Rebeck, K. (2001). Test of economic literacy (3nd ed.). NewYork: National Council on Economic Education.

Yıldırım. A., \& Şimşek. H. (2006). Sosyal bilimlerde nitel araştırma yöntemleri (Qualitative research methods in social sciences). Ankara: Seçkin Publishing

Yiğitbaşı, Ş. (1996). Mikro iktisat (Micro economics). Afyon: Afyon Kocatepe University. 